\title{
How L1 Loanwords Can Create a False Sense of Familiarity with L2 Vocabulary Meaning and Usage
}

\author{
Marie-Emilie Masson \\ Kyushu Sangyo University \\ doi: http://dx.doi.org/10.7820/vli.v02.1.masson
}

\begin{abstract}
Almost $50 \%$ of high-frequency English (L2) words have Japanese cognates in the form of loanwords, and depending on cognate type these are generally considered to be an excellent way to promote vocabulary retention. However, relatively unexplored is the impact loanword cognates have on word usage in sentences. This paper will describe the discrepancies between students' perceived knowledge and actual knowledge of meaning and usage of English words with Japanese cognates. The results suggest that cognates which are usually more difficult for students to retain, such as distant false friends (because they have undergone a semantic shift), are not the only source of difficulty in terms of word usage. In addition to this, it appears loanword cognates that students consider themselves to know can create a false sense of familiarity with L2 meaning and usage. True cognates and convergent cognates, which are generally considered the easiest to recall meaning of, showed the most discrepancies in terms of accurate word usage.
\end{abstract}

\section{Introduction}

Loanword cognates are commonly considered an excellent resource for learning English vocabulary. A broad definition of cognates includes words across languages that have similar forms, which may or may not have similar meanings. Daulton (1999) suggests, Japanese loanwords with English source words can be helpful for Japanese learners who want to increase their L2 vocabulary. In the top 3000 word families of English, at least $45.5 \%$ have some affiliation with Japanese loanwords (Daulton, 2003). However, there has not been enough investigation into the different types of loanword cognates and how they affect learners with regard to meaning and usage (Daulton, 2008).

It has been acknowledged that loanwords can mislead students if the L1 definition deviates substantially from the source word in L2. But as Uchida (2001) points out, loanword cognates are often incorrectly grouped together as a single category of "false friends," when in fact the loanwords can be very different from one another in relation to English and Japanese meanings. Daulton sums up the situation as follows:

These studies ignore the semantic varieties such as true cognates, close/distant false cognates and convergent/divergent cognates, key distinctions in determining the degree of facilitation. The anecdotal condemnation of certain cognates has often led to the 
guilt by association of all. The problem is so endemic that much previous research is in need of re-evaluation; cognates could be made to look quite difficult by including only false friends. (Daulton, 2008, p. 57)

This is problematic as false friends are only one type of loanword cognate. Uchida (2001) argues that while some forms are more difficult to learn, others can facilitate vocabulary retention. In Uchida's taxonomy, there are six types of Japanese-English cognates into which loanwords can be categorized (Figure 1).

True cognates are words that have the same meaning in L1 and L2. Convergent cognates are words that have more meanings in L2 than in L1. For instance, the word baiku in Japanese (from the English bike) only refers to motorbikes, whereas bike can mean either motorbike or bicycle in English. Divergent cognates are words that have more meanings in L1 than in L2. For instance, handoru in Japanese (from the English handle) can refer to any kind of handle, including bicycle handle bars and even a steering wheel. Close false friends are words that have similar forms and meanings. For instance, shiiru in Japanese (from the English seal) means sticker in English. Distant false friends are words which have undergone a semantic shift: the L1 and L2 meanings are no longer the same. For instance, sumaato in Japanese (from the English smart) means slim. Japanized English words have no English equivalent; they are created in Japanese from English loanwords. For instance, sukinshippu, which means physical intimacy in Japanese, is a hybridization of the English source words skin and relationship, but "skinship" does not exist in English.

This categorization has been limited to examining the comprehension of word meaning. Still unexplored is the effect loanword cognates have on word usage. The aims of this study are twofold. 1) To determine whether, depending on cognate type,

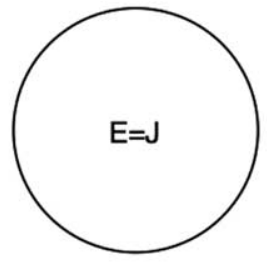

1. True cognates

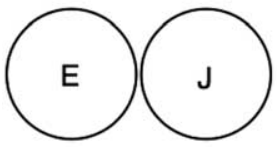

4. Close false friends

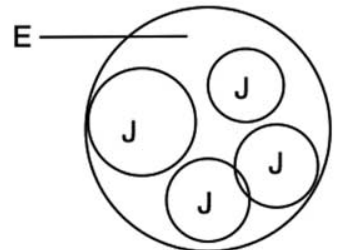

2. Convergent cognates
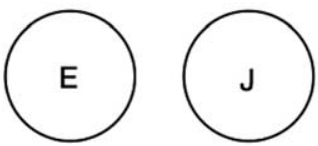

5. Distant false friends

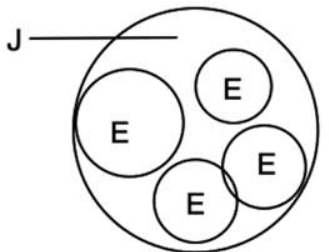

3. Divergent cognates

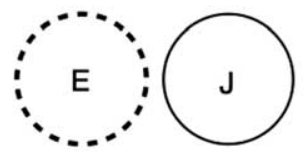

6. Japanized English

\begin{tabular}{|l|l|l|l|l|l|}
\hline $\begin{array}{l}\text { True } \\
\text { cognates }\end{array}$ & $\begin{array}{l}\text { Convergent } \\
\text { cognates }\end{array}$ & $\begin{array}{l}\text { Divergent } \\
\text { cognates }\end{array}$ & $\begin{array}{l}\text { Distant false } \\
\text { friends }\end{array}$ & $\begin{array}{l}\text { Japanized } \\
\text { English }\end{array}$ & $\begin{array}{l}\text { Close false } \\
\text { friends }\end{array}$ \\
\hline
\end{tabular}

Figure 1. Types of Japanese-English loanword cognates and spectrum of difficulty from easiest (not shaded) to hardest (shaded) (adapted from Uchida, 2001). 
loanwords create a false sense of familiarity for students for both L2 word meaning and usage; and, 2) to compare students' self-reported knowledge of loanword cognates with their actual knowledge.

\section{Method}

Three classes in a private Japanese university taught by two teachers, including 55 first- and second-year students averaging 400 on the $\mathrm{TOEIC}^{\circledR}$ test, participated in this study. The students were not English majors but had elected to take part in the course.

Students completed a checklist of 30 English words. Checklists have been shown to be a psychometrically reliable way to check word knowledge (Gibson \& Stewart, 2011). Students were asked to self-report their knowledge of word meaning and usage by choosing between:

(1) I don't know this word,

(2) I've seen this word and I know one meaning,

(3) I know more than one meaning for this word and I can write a sentence using this word.

The words were written in English with their part of speech provided in Japanese. All the words, which had corresponding Japanese loanwords, were randomly selected from the top 2000 spoken English words. One word, which did not meet this criterion, was removed from the analysis, as was a second word, which was mislabeled as a verb. The checklists contained all five types of cognates outlined above, except Japanized English because these words do not have English source words.

Once the checklists were completed, students made sentences with the same items to demonstrate their knowledge of word meaning and usage. The sentences were marked by two teachers to determine whether meaning and usage were demonstrated correctly in contrast to the checklists which measured students' beliefs about word knowledge. Teachers were trained before marking the tests and achieved an inter-rater reliability of over $80 \%$. Words that presented a high ratio of discrepancy were then examined more thoroughly through qualitative linguistic analysis using Nvivo (v.10).

\section{Results and discussion}

As hypothesized by Uchida (2001), distant false friends created the greatest discrepancies. Figure 2 shows that students overestimated their knowledge of word meaning for three loanword cognates in particular: miss (n.), present (v.) and trip (v.).

The words miss (n.), present (v.) and trip (v.) have all undergone semantic transfer as loanwords in Japanese making them distance false friends which are particularly problematic for students who are lulled into a false sense of familiarity, but do not notice that the meaning has changed. 


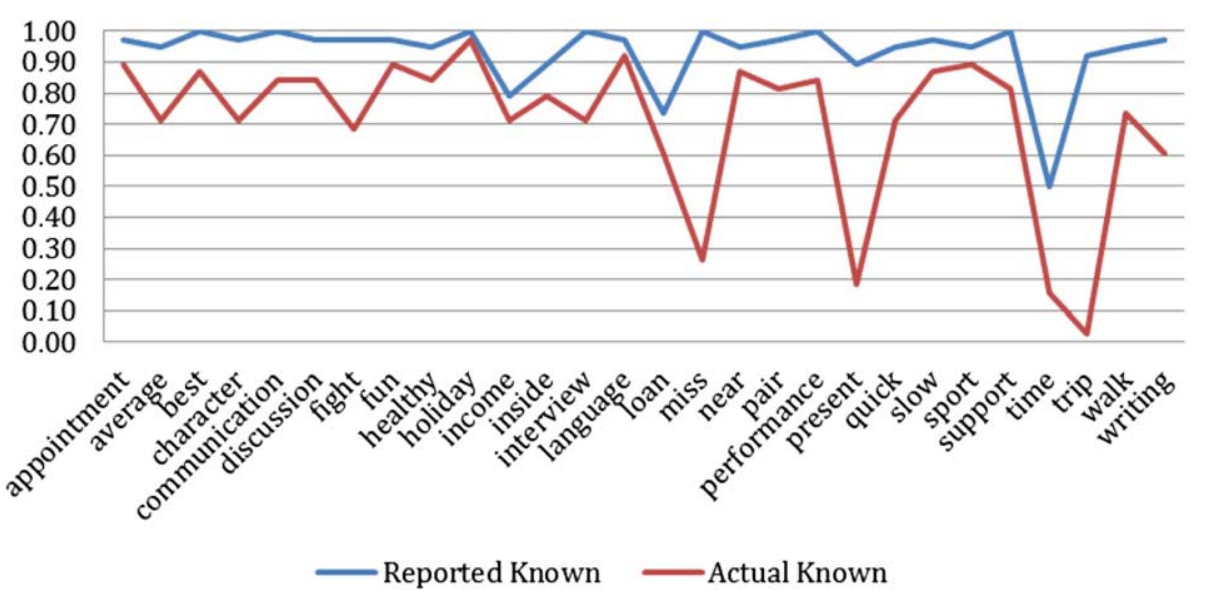

Figure 2. Self-reported knowledge and actual knowledge of word meaning of checklist items.

However, discrepancies in knowledge of word usage showed a different picture. As indicated in Figure 3, in contrast to word meaning, true cognates and convergent cognates, which are considered to be the easiest loanwords for Japanese learners, were the most problematic.

Within words for which the meaning was correctly known, the widest discrepancies were found in the close cognate holiday, and the true cognates communication, discussion, character and sport. This is interesting, because in regard to comprehension of L2 word meaning, true and close cognates are considered to be the least problematic categories, and in fact are considered beneficial for vocabulary retention.

As illustrated by Figure 2, meaning is well known for true cognates and convergent cognates. However, Figure 3 shows convergent cognates and true cognates are the most problematic for students in terms of usage.

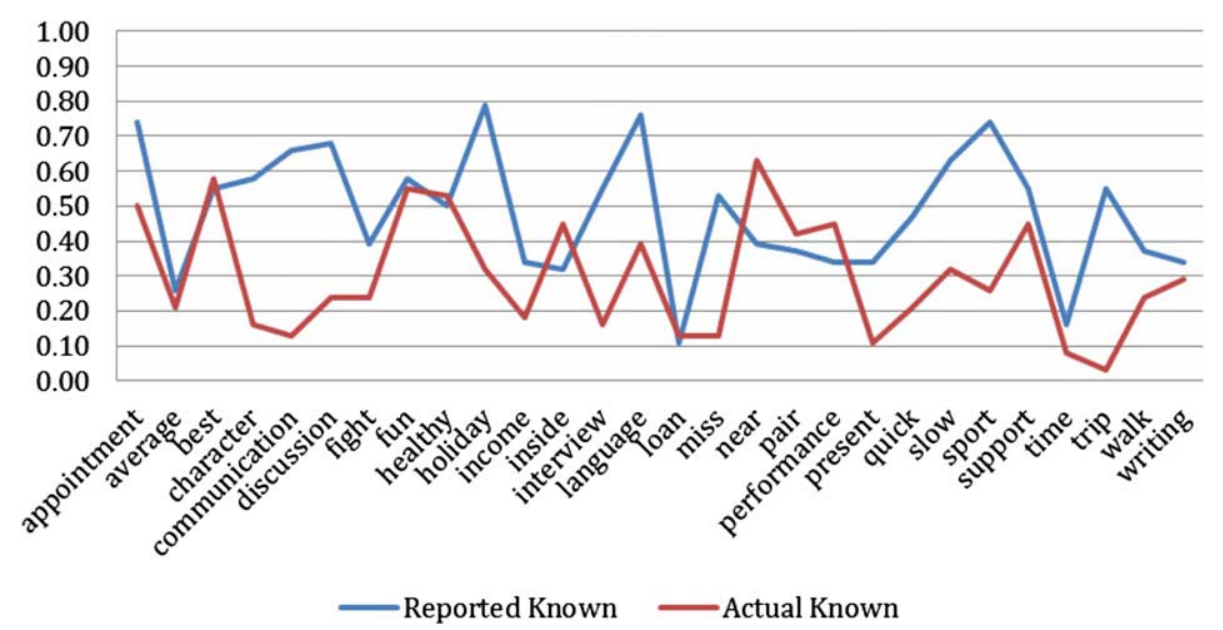

Figure 3. Self-reported knowledge and actual knowledge of word usage of checklist items. 
What follows is a qualitative analysis of errors made with this convergent cognate and these true cognates. There were two major categories where misuse was identified: the use of collocations and word placement. The following example sentences are transcribed as students wrote them on the productive test. They are numbered in order of appearance.

\subsection{The use of collocations}

Students showed difficulty in using particles, particularly with the word holiday. In Japanese, the loanword for holiday is mainly read in the names of companies or clubs that want to sound exotic or progressive (as in ホリデイスポーツクラブ) or to express the idea of traveling to a foreign place (as in ワーキングホリデー), but it is rarely used in daily conversation. Due to its meaning, students may be applying the same connective logic to holiday as other words used to express location, such as in New York, or static periods of time, such as in December or in summer.

$\operatorname{HOLIDAY}(\mathrm{n}$.

(HOLIDAY: on holidays)
$01{ }^{*}$ My family often go to picnic in a holiday.

$02{ }^{*}$ I went shopping with my friend in holiday.

An overview of the different particles used to connect adverbial phrases of time, place, cause, consequence, among others, is one way to assist students with mastering this type of collocation.

Students also had difficulty with verb-noun associations, particularly with the words communication and discussion. Both of these words are commonly used as loanwords in spoken Japanese. Their non-loanword equivalents (伝達 and 討論, respectively) carry a somewhat archaic nuance reserved for describing exchanges in very serious formal settings. In Japanese, the noun コミュニケーション (komyunikeeshon) is collocated with the verb toru (to take), and the noun ディスカッション (disukasshon) is collocated with the verb suru (to do).

COMMUNICATION (n.) 03 *The nurce need to study how to take communication with illness. (COMMUNICATION: enter into communication)

DISCUSSION (n.) $\quad 04$ *We did the discussion for class everyday.

$05 *$ must do discussion with my friend, because our homework.

(DISCUSSION: have a discussion)

Encouraging students to investigate verb-noun associations in L2, by using a dictionary or the Internet (Park \& Kinginger, 2010), will help develop their interlanguage. Teachers can use these examples to demonstrate to students that content words, along with their associated verbs and functions words, ought to be learned as chunks. 


\subsection{Word placement}

Japanese is a topic-prominent language that is situation-focused (Wlodarczyk, 1996); the meaning of a sentence centers on a topic or a shared situation. The topic is generally made explicit, whereas the subject does not need to be. English is a subject-prominent language, meaning the sentence will be constructed around the grammatical subject, and the topic can be inferred.

Character and sport are both true cognates commonly used in Japanese. In both cases, the first meaning for the Japanese loanword corresponds to the first meaning of the word in English. In sentences 06 through 11, the students have topicalized the true cognates. With character, the word has also become the subject. Although character can be used as a subject, the collocation has a bad character, in which the word character is used as an object, and is much more common in English. With sport, the word is being made explicit as the topic of the sentence. This results in the sentence sounding redundant as the topic of "sports" can be inferred from the content of the sentence, in this case the individual sports (e.g., baseball, tennis, and soccer).

CHARACTER (n.)

$\operatorname{SPORT}(\mathrm{n}$.

\author{
06 *Your charactor is shy I think. \\ $07{ }^{*}$ His charactor is very bad so everyone don't like him. \\ 08 * $\mathrm{Her}$ charactor was very nice so she have many friends. \\ 09 * Which do you like sport soccer or baseball? \\ 10 * l like sport tennis, soccer, volleyball and so on. \\ $11{ }^{*}$ l like doing some sports baseball and tennis.
}

This difference in perspective when building sentences is another challenge for Japanese students which shows that true cognates, where the first meaning of the word corresponds in both languages, is not a guarantee that students will be able to use the words successfully in their L2. Teachers can help students by showing them how to separate the topic and subject of a sentence and how to infer the topic.

\section{Conclusion and future directions}

Research has shown that certain types of Japanese-English cognates can be beneficial to student vocabulary acquisition, with distant false friends among the most challenging for students and true cognates among the easiest (Uchida, 2001). However, as demonstrated in this study, the opposite pattern can be observable with regard to word usage; although meaning is well known for true cognates and convergent cognates, usage is poorly understood. While beneficial for learning L2 word meanings, these types of cognates can create a false sense of familiarity for students and dissuade them from studying L2 vocabulary beyond word-to-word meaning. As educators, it is possible that because students understand the meaning of true and close cognates with a high degree of facilitation, we focus less instruction on them, when in fact these words remain a challenge to students.

In future, an extensive investigation of student knowledge of loanword meaning and usage according to cognate type is necessary to understand how each category affects students' learning. In order to assist educators with a vocabulary 
component to their courses, a detailed qualitative analysis of students' written output, using various types of loanword cognates to determine the difficulty level of each type, in terms of usage, and the kinds of challenges students face when incorporating these words to their L2 output is needed.

\section{References}

Daulton, F.E. (1999). English loanwords in Japanese - The built-in lexicon. The Internet TESL Journal, 5 (1). Retrieved from http://iteslj.org/Articles/Daulton-Loanwords.html

Daulton, F.E. (2003). List of high frequency baseword vocabulary for Japanese EFL students \# 2. The Internet TESL Journal, 9 (3). Retrieved from http:// iteslj.org/lists/Daulton-BasewordVocab2.html

Daulton, F.E. (2008). Japan's built-in lexicon of English-based loanwords. Clevedon \& Philadelphia, PA: Multilingual Matters.

Gibson, A., \& Stewart, J. (2011). Using yes/no tests to examine the relationship between frequency and difficulty in the vocabulary knowledge of second language learners. Kyushu Sangyo University Language Education and Research Center Journal, 6, 23-35.

Park, K., \& Kinginger, C. (2010). Writing/thinking in real time: Digital video and corpus query analysis. Language Learning \& Technology, 14 (3), 30-49. Retrieved from http://1lt.msu.edu/issues/october2010/parkkinginger.pdf

Uchida, E. (2001). The use of cognate inferencing strategies by Japanese learners of English (Ph.D. dissertation, University of Essex).

Wlodarczyk, A. (1996). La thématisation en japonais et l'article français. In V. Koseska-Toszewa \& D. Rytel-Kuc (Eds.), Semantyka a Konfrontacja Jezykowa [Semantics and contrast between languages] (pp. 131-139), Warszawa: PAN-SOW. 